\title{
Innovative Furniture Design for Lease House Occupant in Merauke
}

\author{
$1^{\text {st }}$ Muchlis Alahudin \\ Department of Architecture \\ Universitas Masumus \\ Merauke \\ muchlisalahudin@y ahoo.co.od
}

\author{
$2^{\text {nd }}$ Anton Topan \\ Department of Architecture \\ Universitas Masumus \\ Merauke
}

\author{
$3^{\text {rd }}$ Martha Loupatty \\ Department of Physic \\ Universitas Masumus \\ Merauke
}

\begin{abstract}
Lease house is one of the most residential which was built with gain less attention by comfort, as thermal comfort (temperature, humidity, solar radiation, etc) and activity comfort. All lease house's room was planned and designed without calculating the maximum quantity of room. It's just only impression that "the important thing is existing of the room". The purpose of this research is socializing the utilization of innovative furniture for increase support the comfortable of lease house in Merauke also make furniture that can be used in all of the rooms in lease house (except bathroom and water closet) by innovative furniture application. The result of this research is expected that will get an innovative furniture which effective, comfort, safe, healthy and efficient. The characteristic of this research is descriptive, evaluative and applicative. It means that collecting the data by observation, total population, age, height, weight, job measure, anthropometry measure (elbow high and vertical range, sitting motion, height) also literature study. Data analysis of this research is quantitative descriptive which using frequency tabulation also qualitative which using spatial pattern description. The average size of lease house for a unit in Merauke is $49 \mathrm{~m} 2$ which use standard furniture for a bedroom (bed, cupboard and desk) and only $20 \%$ space of lease house for circulation. So, it will make the room becomes narrow. If we use innovative furniture, the space of lease house for circulation becomes $35 \%$. It means that if we use innovative furniture, the circulation will increase $15 \%$ better than standard furniture. Furthermore, this circulation is so good for human, temperature also humidity in the lease house's room.
\end{abstract}

Keywords - Innovative furniture, ergonomics, Unmus, Merauke

\section{INTRODUCTION}

Alahudin, Jayadi [1], the Thermal condition of the lease house in Merauke are very uncomfortable with $29 \mathrm{oC}-32 \mathrm{oC}$ of temperature and $72 \%-80 \%$ of humidity while $0,3 \mathrm{~m} / \mathrm{s}$ of wind speed in the building. The condition indicates that it is very uncomfortable although using the air conditioner. However, the economic condition of a resident in the lease house is unable to use the air conditioner. Besides the condition of lease house which in a row (coupling), the environmental condition around the lease house is not good. In addition, there are so many furnitures and condition of furniture are not well arranged. So, it will affect the thermal condition in the building (uncomfortable), such as increased temperature and air circulation is not fluent. The narrow condition of lease house with many needs will require some furniture. If the furniture selection is not wise, it will affect to the building comfortable, the room will be full of the existing furniture. Especially for the market in Merauke, the size of furniture still very large and only have one function. So, the resident of lease house must complete all the furniture requirements and it a certainty the circulation of lease house will decrease if so many furnitures in there.

The idea for make furniture for the small house will get attention nowadays, but innovative furniture still hard to find it in Merauke. So that, it needs technology application research which compatible with lease house needs in Merauke. The finding target of this research is an innovative and multi function furniture model which effective, comfort, safe, healthy and efficient especially in Merauke.

\section{A. Ergonomic Furniture}

Beddu S, and friends [2]. In this globalization era, every human behaviour is demanded an effective and efficient activity in their job. In automatically, every human will need many various tools to support their job. Every tool includes furniture needed standard procedure based on human factors or the right Ergonomic accordance with Human Dimension (dimension of body measurement) when they were activating. Using of ergonomic will affect to the person who uses that furniture indirectly. The furniture user will feel comfort and relax if they use furniture rightly and correctly with human ergonomic standard elements [3]. 


\section{B. Thermal Comfort}

Alahudin, Jayadi based on his analysis of the measure, record and observation on lease house, thermal condition of its building are:

1. Air temperature influence, by result analysis of temperature range in the building is $29^{\circ} \mathrm{C}$ until $32^{\circ} \mathrm{C}$, while the average temperature outside the building is $28^{\circ} \mathrm{C}$ until $31^{\circ} \mathrm{C}$. All of the conditions are warm until hot.

2. Humidity influence, the average humidity inside or outside the building is $72 \%$ until $80 \%$. At 08.00 until 09.00 , its humidity reaches $80 \%$ which can be categorized as stuffy condition, after that it will decrease until less comfortable humidity at 10.00 until 16.00. the cause of high humidity is less of house's opening and unfluently of air circulation. it also causes by poor ventilitation and the amount of excessive furniture.

3. Air movement influence, the speed of air movement is very important in creating a comfort condition. if seen by house's opening which less fulfills. the average of wind speed in the building is not exceeding $0,3 \mathrm{~m} / \mathrm{s}$ while wind speed outside the building can reach 0,7 $\mathrm{m} / \mathrm{s}$. Obstacle factors of air enterance to the building are the orientation of building direction which not having the same aim with the wind movement, less of placement vegetation closely and less of house's opening.

The Climate influence on room's thermal also measures results.

1. Lease house Condition

- Lease house area : 7,20 m x 3,50 m

- Window : $70 \mathrm{~cm} \times 130 \mathrm{~cm}$ for window's dimension using jalousie window with two windows on the front side.

- Door : $210 \mathrm{~cm}$ x $80 \mathrm{~cm}$ for door's dimension with two doors, it consists of living room's door and bedroom's door while the dimension of bathroom's door is $210 \mathrm{~cm} \times 70 \mathrm{~cm}$.

- Roof material : Fabrication material such as corrugated iron sheets.

2. Environmental Condition

- Vegetation : The vegetation around Lease house is very less. The nearest vegetation is a cermela tree.

- Other Building : the sample of Lease house is a part of a long building which divided by some partition, another building is Lease house exact in front of sample house and mutual facing. Location of sample house in the dense area of the building.

3. The Climate influence on room's thermal also measures results.

a. Air temperature influence

Difference of inside and outside temperature :

- $08.00-10.00 \quad$ : Warm Comfort, building inside temperature is $29^{\circ} \mathrm{C}$ until $31^{\circ} \mathrm{C}$ and building outside temperature is $28,5^{\circ} \mathrm{C}$ until $31^{\circ} \mathrm{C}$.

- $11.00-13.00$ : Hot, building inside temperature is $31^{\circ} \mathrm{C}$ until $32,5^{\circ} \mathrm{C}$ and building outside temperature is $30,5^{\circ} \mathrm{C}$ until $31,5^{\circ} \mathrm{C}$.

- $14.00-16.00$ : Hot, building inside temperature is $31^{\circ} \mathrm{C}$ until $31,5^{\circ} \mathrm{C}$ and building outside temperature is $30^{\circ} \mathrm{C}$ until $31,5^{\circ} \mathrm{C}$.

b. Air humidity influence

Air humidity influence (\%) inside building (average : $75,5 \%$, minimal : $74,04 \%$ and maximum : $76,6 \%$ ) while outside building (average : 76,28\%, minimal : $75,7 \%$ and maximum : $78,6 \%$ ). If seen by the percentage of humidity is known that $70 \%$ entrance of humidity in the category of less comfortable, while the percentage of humidity in the house $70 \%$ above average. So, it categorized as less comfortable nearest the stuffy condition with $80 \%$ of humidity percentages.

c. Wind speed influence

Wind speed influence $(\mathrm{m} / \mathrm{s})$ inside building (average : $0,04 \mathrm{~m} / \mathrm{s}$, minimal $0 \mathrm{~m} / \mathrm{s}$ and maximum $0,08 \mathrm{~m} / \mathrm{s}$ ) while outside building (average : $0,4 \mathrm{~m} / \mathrm{s}$, minimal $0,3 \mathrm{~m} / \mathrm{s}$ and maximum $0,5 \mathrm{~m} / \mathrm{s}$ ).

4. Information

- The peak temperature condition of Lease house is at 11.00 until 13.00 , while the highest temperature condition is at 12.00 .

- The building condition and environmental around is very influencing the thermal inside building. Besides of that, the less vegetation will increase the temperature inside the building.

- Roof material is influencing temperature and humidity inside the building.

- The existance of building around will be the obstacle factors of air enterance to the building.

The less of house's opening will make the air enterance into the house are very less. So, it is not influencing the building thermal.

\section{RESEARCH METHOD}

Steps of this research include Lease house study (ergonomic spase and occupant anthopometry). The steps are:

1. Measuring the occupant anthopometry of Lease house

2. Setting up plans of innovative furniture

3. Making the innovative furniture

4. Testing of furniture (Trial process at Universitas Musamus)

5. Completing the furniture

6. Testing of innovative furniture operational at the field (Lease house which is as research place and general society)

There are documentations by observation result directly. This observation which is as watch closely are quantity by every lease house unit, quantity by every space in the lease house, the quantity of furniture and furniture in amount. 
Besides of that, the direct interview has a purpose to get information by an informant (Lease house owner and tenant) for collecting the data.

By interview, we can get some information, they are :

1. Unit of lease house in amount

2. Measure of lease house

3. Data of tenant (height, weight, age and occupation).

4. Furniture owned in amount.

Data processing for review the respondent's answers (information) in each question which has been submitted during an interview to conform to the established rules. After that analysis the data. The analysis is :

1. Building analysis (area of lease house, space area in lease house, furniture in amount for each space in lease house, the quantity of furniture and circulation).

2. Anthopometry analysis

Occupants analysis by sex, age, weight and height.

\section{RESULT AND DISCUSSION}

This research was done on lease house which randomly selected because there are many lease house in Merauke. Research result shows that the average of lease house area is $48 \mathrm{~m}^{2}$.Study object for bedroom shows that its area is $9 \mathrm{~m}^{2}(3 \mathrm{~m}$ $\mathrm{x} 3 \mathrm{~m})$.

TABLE I. ROOM QUANTITY BEFORE USING THE INNOVATIVE FURNITURE

\begin{tabular}{|c|l|c|c|c|c|}
\hline $\begin{array}{c}\text { Room } \\
\text { Type }\end{array}$ & $\begin{array}{c}\text { Furniture } \\
\text { Type }\end{array}$ & $\begin{array}{c}\text { Length } \\
(\mathbf{m})\end{array}$ & $\begin{array}{c}\text { Wide } \\
(\mathbf{m})\end{array}$ & Amount & $\begin{array}{c}\text { Area } \\
\left(\mathbf{m}^{\mathbf{2}}\right)\end{array}$ \\
\hline \multirow{4}{*}{ Bedroom } & Bed & 2.0 & 1.8 & 1 & 3.60 \\
\cline { 2 - 6 } & Cupboard & 1.2 & 0.4 & 1 & 0.48 \\
\cline { 2 - 6 } & Desk & 0.8 & 0.6 & 1 & 0.48 \\
\cline { 2 - 6 } & Chair & 0.5 & 0.4 & 1 & 0.20 \\
\cline { 2 - 6 } & Human & 1.2 & & 2 & 2.40 \\
\hline \multicolumn{5}{|c|}{ Total Area } & \\
\hline
\end{tabular}

The total area of bedroom furniture is $7.26 \mathrm{~m}^{2}$ while lease house area is $9 \mathrm{~m}^{2}$ which filled by a double bed, a cupboard, a desk and $20 \%$ from the area for circulation. Based on circulation standard, this $20 \%$ use for circulation needs, while this $20 \%$ of circulation is not good enough because there are two or more persons in that room.

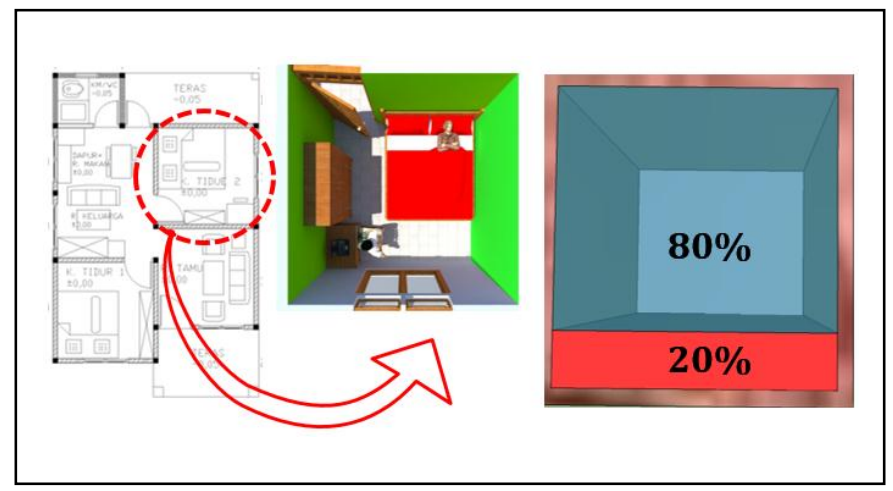

Fig. 1. Room circulation before using the innovative furniture
TABLE II. ROOM QUANTITY AFTER USING THE INNOVATIVE FURNITURE

\begin{tabular}{|c|l|c|c|c|c|}
\hline $\begin{array}{c}\text { Room } \\
\text { Type }\end{array}$ & $\begin{array}{l}\text { Furniture } \\
\text { Type }\end{array}$ & $\begin{array}{c}\text { Length } \\
(\mathbf{m})\end{array}$ & $\begin{array}{c}\text { Wide } \\
(\mathbf{m})\end{array}$ & Amount & $\begin{array}{l}\text { Area } \\
\left(\mathbf{m}^{\mathbf{2}}\right)\end{array}$ \\
\hline \multirow{3}{*}{ Bedroom } & Bed & 2.16 & 1.36 & 1 & 2.9376 \\
\cline { 2 - 6 } & $\begin{array}{l}\text { Multi- } \\
\text { function } \\
\text { cupboard }\end{array}$ & 1.20 & 0.4 & 1 & 0.48 \\
\cline { 2 - 6 } & Human & 1.20 & & 2 & 2.40 \\
\hline \multicolumn{6}{|c|}{ Total Area } \\
\hline
\end{tabular}

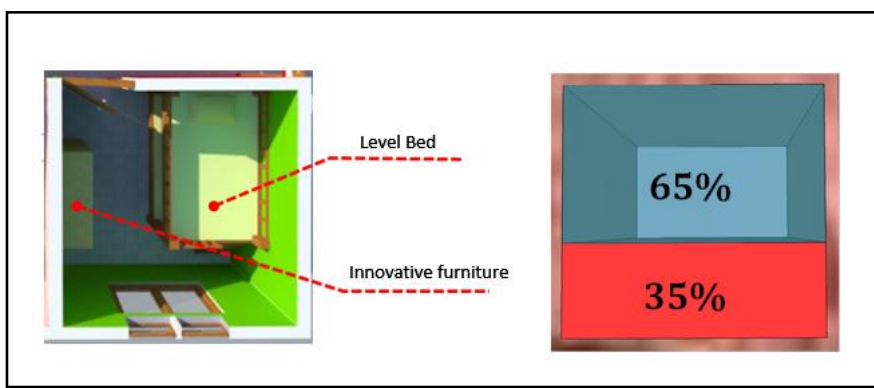

Fig. 2. Room circulation after using the innovative furniture

This innovative furniture ever tested to the society (on Universitas Musamus Celebration, November $19^{\text {th }}, 2016$ ) which was done as many as 27 furnitures into the innovative furniture. By 47 respondents of this research, 46 respondents said that this furniture is so innovative and satisfied, while one respondent didn't answer anything.

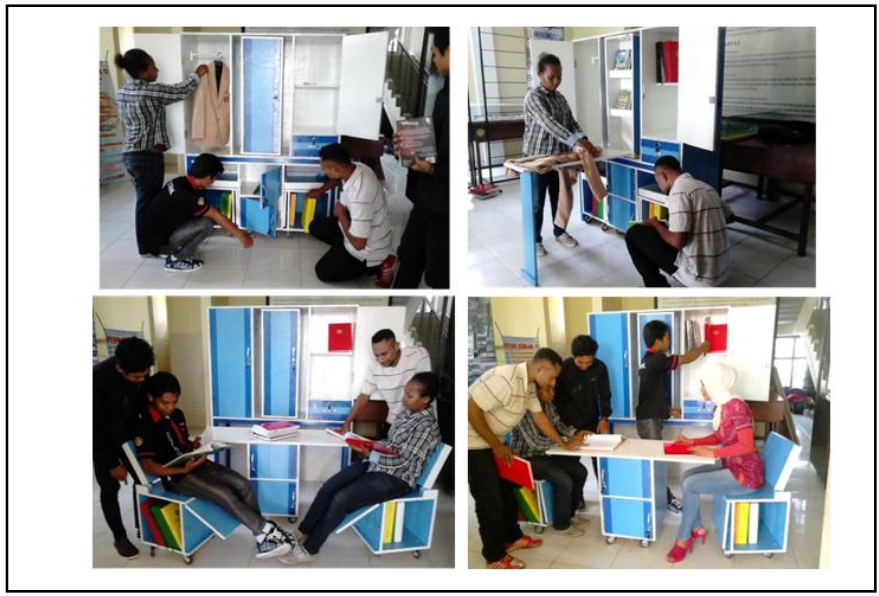

Fig. 3. Result of innovative furniture design

\section{CONCLUSION}

By the research of innovative furniture design for lease house in Merauke, we can conclude that:

1. The tenant of lease house has not a choice when purchasing furniture for their needs.

2. The average area for a unit of lease house is $49 \mathrm{~m} 2$.

3. By using furniture which exists in the market and bedroom standard needs (bed, cupboard and desk), only $20 \%$ space for circulation from $9 \mathrm{~m} 2$ of the area. So, the area becomes narrow while if we use innovative furniture, the circulation becomes $35 \%$. It means that by 
using innovative furniture, the circulation will increase $15 \%$ better than standard furniture. this thing is so good for human circulation, air and humidity temperature in

Suggestion: the building.

1. The tenant of lease house must more carefully in choosing the furniture which will use.

2. Laying down of furniture must have attention in the narrow room.

3. Need more design development for other innovative furniture for lease house (bed, chair and others).

\section{REFERENCES}

[1] Alahudin, M. Jayadi, 2014. Kondisi Lingkungan Sekitar Terhadap Kenyamanan Termal Rumah Sewa (Studi Kasus Rumah Sewa Di Kel. Seringgu Jaya Merauke). Mustek Anim Ha Vol. 3 no. 1 April. Universitas Musamus. Merauke.

[2] Beddu S., dkk 2012. Studi Ergonomi Furnitur Jurusan Arsitektur Fakultas Teknik Universitas Hasanuddin (Studi Kasus : Meja Dan Kursi Di Jurusan Arsitektur). Prosiding Fakultas Teknik Universitas Hasanuddin

[3] Marizar Eddy S, 2005. Designing Furniture Teknik Merancang Furnit ur Kreatif (Konsepsi, solusi, inovasi, dan implementasi). Yogyakarta: Media Pressindo. 